5. Coronavirus chinois : la quarantaine est-elle une mesure efficace pour éviter la propagation ? URL: https://www.lemonde.fr /planete/article/2020 /01/28/coronavirus-chinois-la-quarantaine-une-mesure-de-precautionancienne-a-l-efficacite-tres-relative_6027513_3244.html (дата звернення: 26.10.2020)

6. Bouissou J., Leplâtre S. L'épidémie de coronavirus a stoppé net l'économie de la Chine. URL: https:// www.lemonde.fr/ economie/ article/2020/02/04/ coronavirus-1-economie-chinoise-est-a-1-arret_6028357_ 3234.html (дата звернення: 26.10.2020)

7. Cosnard D. Le confinement, cette parenthèse enchantée où la nature a repris ses droits. URL: https://www.lemonde.fr/m-styles/article/ 2020/07/16/le-confinement-cette-parenthese-enchantee-ou-la-nature-a-reprisses-droits_6046325_4497319.html (дата звернення: 27.10.2020)

DOI https://doi.org/10.30525/978-9934-588-90-7-45

\title{
LINGUISTIC SYNTAGMATICS IN THE VERBAL CONFLICT
}

\author{
Chayka L. V. \\ Doctor of Philology, \\ Associate Professor of the Foreign Languages Department Research and \\ Educational Center of Foreign Languages \\ National Academy of Sciences of Ukraine \\ Kyiv, Ukraine
}

\section{Onuchak L. V.}

PhD in Pedagogy, Associate Professor, Head of the Modern European Languages Department

University of State Fiscal Service of Ukraine

Irpin, Kyiv region, Ukraine

The concept of verbal conflict is such a violation of the human communication process, when one of the communicants does not fully or partially understand the other, has a negative attitude to his/her manner of speech behavior, verbal-cognitive base or to the signs used in the communicative act. The verbal conflict concept provides an opportunity to generalize and theoretically comprehend the whole complex of similar phenomena of speech interaction, which were previously either studied sporadically or not included in a number of linguistic objects at all. 
Intralinguistic sign deformations are conflictogenic factors that mark the extra-linguistic properties of communicants with linguistic means, performing the task of verbalizing sociolinguistic and psycholinguistic reasons for generating verbal conflicts; the discrepancy between the constructive means chosen by the addresser and the addressee's expectations is perceived by the latter as a sign deformation and is potentially capable of generating a verbal conflict.

One should distinguish: 1) deformations proceeding along the line of sign systems (various types of mixture of a language existence forms, social and territorial dialects; interlingual mixing - individual interlingual interference); 2) synchronous sign deformations: a) exponential deformations: articulation errors - accent; confusion of phonemic oppositions; syllabic transformations; accentological errors; paronymic attraction; violation of the tonic structure of words and syllables; b) semantic sign deformations: ambiguity of the words' semantic differential; mixing of the direct and figurative meanings of the word; mixing of homonyms; 3 ) paradigmatic (synchronic) deformations while using grammatical categories - and syntagmatic (synchronic) - referential conflicts; violation of the rules for complicating sentences; erroneous or difficult to understand inversion; deformations of the integrity and coherence of the text;4) diachronic sign deformations - they are associated with the perception of speech acts created at an earlier section of the language development than the section of the speech addressee; 5) deformations of the written signs: illiteracy or negligence; difficulty in visual perception of the text; erroneous identification of graphemes; individual prejudices of both the addresser and addressee, including those associated with special states of their consciousness.

Let us consider syntagmatic deformations associated with a set of sign relations in the language system itself, as they seem to communicants in the verbal conflict situation.

Syntagmatic sign deformations are determined by the linear nature of the arrangement of signs in the speech chain. They are characterized, e.g. by a violation of the formal-syntactic structure of a simple sentence: in the presence of certain lexical occurrences, this can lead to misunderstanding or ambiguity [10, p. 280-291] and generate a verbal conflict on this basis: When she entered the room, Betty saw a lot of people, where it is impossible to understand how words are related on a formal level. A kind of such sign deformations is the socalled referential conflict that arises "if another referent, different from the correct one, can be compared to the selected nomination" [5, p. 129]. The referential conflict is compensated through the employment of competing referents and compliance with the propositional context [5;9]. 
The violation of the text coherence definitely leads to a verbal conflict: There's whatdoyoucallhim out of. How do you? Doesn't see. Chap you know just to salute bit of a bore. His back is like that Norwegian captain's. Wonder if I'll meet him today. Watering cart. To provoke the rain. On earth as it is in heaven. A cloud began to cover the sun wholly slowly wholly. Grey. Far. (J. Joyce). In the above passage, the author wants to express those meanings that belong to internal speech due to the loss of the formal grammatical and semantic integrity of the utterance, which greatly complicates understanding.

The stream of consciousness is an artistic technique, but its understanding also requires significant efforts of the reader as a second communicant, for example, the following text: Yes because he never did a thing like that before as ask to get his breakfast in bed with a couple of eggs since the City arms hotel when he used to be pretending to be laid up with a sick voice doing his highness to make himself interesting to that old faggot Mrs Riordan that he thought he had a great leg of and she never left us a farthing all for masses for herself and her soul greatest miser ever was actually afraid to lay out $4 d$ for her methylated spirit telling me all her ailments she had too much old chat in her about politics and earthquakes and the end of the world let us have a bit of fun first God help the world if all the women were her sort down on bathingsuits and low-neck of course nobody wanted her to wear I suppose she was pious because no man would look at her twice I hope I'll never be like her... needs a targeted reconstruction of the punctuation structure for the implementation of division into sentences and superphrasal unities. On the other hand, the text of this kind acquires its own meanings in a work of fiction.

A meaningless linguistic text is also found in J. Joyce's novel : «The natural grammatical transition by inversion involving no alteration of sense of an aorist preterite proposition (parsed as masculine subject, monosyllabic onomatopoeic transitive verb with direct feminine object) from the active voice into its correlative aorist preterite proposition (parsed as feminine subject, auxiliary verb and quasimonosyllabic onomatopoeic past participle with complimentary masculine agent) in the passive voice», where the combination of words is determined only terminologically, i.e. through the correlation of the text with a certain (linguistic) field of activity.

In our opinion, conflictogenic factors are the causes of verbal conflicts, but not the "communicative failures" themselves, as O. A. Zemskaya, B. Yu. Gorodetsky et al believe. This is not an integral fact of a verbal conflict, but only one of the stages of its course, which makes it possible to build the proposed classification based on a limited number of basic taxa, and even if other parameters are chosen for constructing a typology (e.g. "misunderstanding" or "negative estimates"), then, in the end, for the 
purpose of explanation, they will still be reduced to the identified three groups, which are stipulated by the close connection of language with social reality and the biopsychophysiological mechanisms of the individual, i.e. by that "non-rigid isomorphism" of the linguistic system in relation to the physical world, with the society and an individual (a linguistic personality).

\section{References:}

1. Алпатов В. М. История одного мифа: Марр и марризм. М. : Наука, 1991. $288 \mathrm{c}$.

2. Виноградов В.В. О языке художественной литературы. М. : Гослитиздат, 1959. 655 с.

3. Гавенко В. Л., Бітенський В. С. Психиатрия и наркология (учебник) = Психіатрія і наркологія (підручник). К.: Здоров'я, 2009. $512 \mathrm{c}$.

4. Зощенко М. М. Избранное. М.: Художественная литература, 1979. $423 \mathrm{c}$.

5. Кибрик А. А. Механизмы устранения референциального конфликта в русском языке. Моделирование языковой деятельности в интеллектуальных системах / Ред. А. Е. Кибрик, А. С. Нариньяни. М.: Наука, 1987. С. 128-146.

6. Шишмарёв В. Ф. Работа Н. Я. Марра в области языков романогерманского мира). Против вульгаризачии и извращения марксизма в языкознании: Сборник статей. Под ред. В.В.Виноградова и Б. А. Серебренникова. Ч. 1-2. М.: АН СССР. Ин-т языкознания, 19511952. T. 1. C. $365-383$.

7. Язык и личность. Отв. ред. Д. Н. Шмелев. М. : Наука, 1989. 211 с.

8. Языковедные проблемы по числительным. 1. Сб. ст. Л.: Изд. Ин-та литератур и языков Запада и Востока, 1927. 210 с.

9. Kibrik A. A. Reference in Discourse. Oxford: Oxford University Press, 2011. $651 \mathrm{p}$.

10. Piantadosi S. T., Tily H., Gibson E. The Communicative Function of Ambiguity in Language. Cognition. 2012. Vol. 122 (3). Pp. 280-291. 